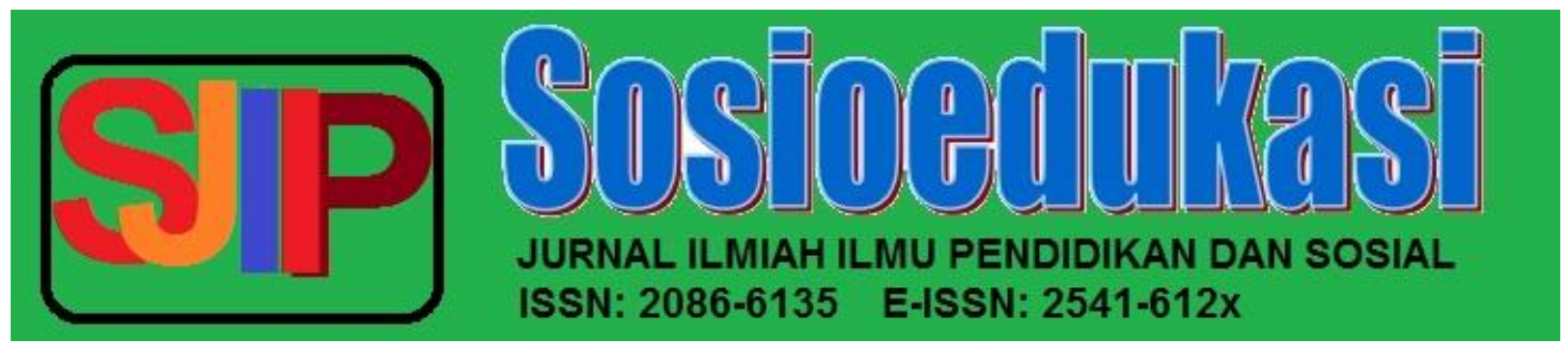

November Vol.9 No. 2 Tahun 2020 https://ejournal.unibabwi.ac.id/index.php/sosioedukasi/index

\title{
PROPOSAL DESIGN OF PROGRAM EVALUATION
}

\author{
Rivan Ardi Yuniangga \\ SMA Muhammadiyah 2 Genteng Banyuwangi \\ ryuniangga@gmail.com
}

\section{ARTICLE HISTORY}

Received : 2310-2020

Revised : $18-10-2020$

Accepted : 17-11-2020

KEYWORDS

evaluasi ;

proposal ;

kegiatan;

\section{ABSTRACT}

This research is the result of observations made by researchers at SMA Muhammadiyah 2 Genteng Banyuwangi. This research is related to several evaluation programs implemented in schools. Every evaluation program definitely needs a proposal that is used to build an implemented evaluation program. The method used in this research is descriptive qualitative. The data obtained were then presented in the form of words and narratives which were presented in depth. The informants in this study were from several school elements ranging from educators, education personnel and other employees. Determination of informants in this study is by purposive sampling where the researcher determines and chooses first who the informants are to support the compilation of this research report. The results obtained from this research are that with the existence of a proposal, every activity carried out will feel more helpful and light because the proposal can be used as a forum to convey meanings and objectives. In addition, proposals are also used to clarify and distinguish some of the elements contained in the activity, starting from the title, meaning and purpose, core and closing.

\section{INTRODUCTIONS}

Program evaluation aims to achieve knowing the achievement of program objectives to be implemented. Then the results of program evaluation are used as a basis for carrying out follow-up activities or for making subsequent decisions. Like research, program evaluation requires a proposal and evaluation design. The difference between a program evaluation proposal and a program evaluation design lies in the emphasis on its content. If the proposal is an activity proposal, the design is a map of the activity journey that will be carried out by the evaluator in carrying out the evaluation. 


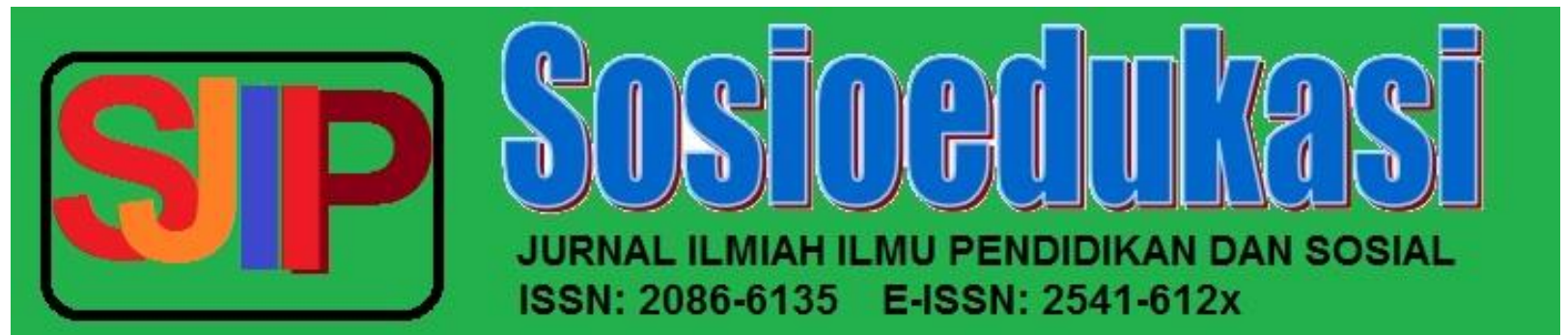

November Vol.9 No. 2 Tahun 2020 https://ejournal.unibabwi.ac.id/index.php/sosioedukasi/index

A program is not just a single activity that can be completed in a short time, but is a continuous activity because it implements a policy. Therefore, a program can take a relatively long time.

Problem Formulation

1. What is meant by the draft program evaluation proposal? 2. How is the draft general program evaluation proposal?

2. How is the service program evaluation proposal draft?

3. How is the draft process program evaluation proposal?

\section{MATERIALS AND METHODS RESEARCH LOCATION}

This paper is written based on research using qualitative methods with the type of case study research that focuses more on program evaluation design. The author conducted in-depth and structured interviews with all elements of the Kasihan Muhammadiyah Senior High School. This subject search technique uses purposive sampling technique, (sampling technique is based on certain objectives). Because the samples were taken according to certain criteria to get a thorough understanding of the problems in this study. The criteria for determining informants in this study are based on evaluation of all elements in the school to improve the existing structure in it. Based on these criteria the researcher tries to select and narrow the informants in order to achieve the desired research objectives in this study. There were ten people interviewing researchers consisting of several educators and education staff, students and some school elements who assist in school activities. Researchers also use research instruments that support this research, including cameras and recording devices that can document any data obtained. From this data it will be processed and presented into a research report.

\section{RESULTS AND DISCUSSIONS}

\section{A. Design Of Program Evaluation Proposal Program}

evaluation is a process, in which evaluation explicitly refers to the achievement of objectives while implicitly evaluating must compare what has been achieved from the program with what should be achieved based on predetermined criteria. In the context of program implementation, the criteria in question are the criteria for the success of the implementation and 


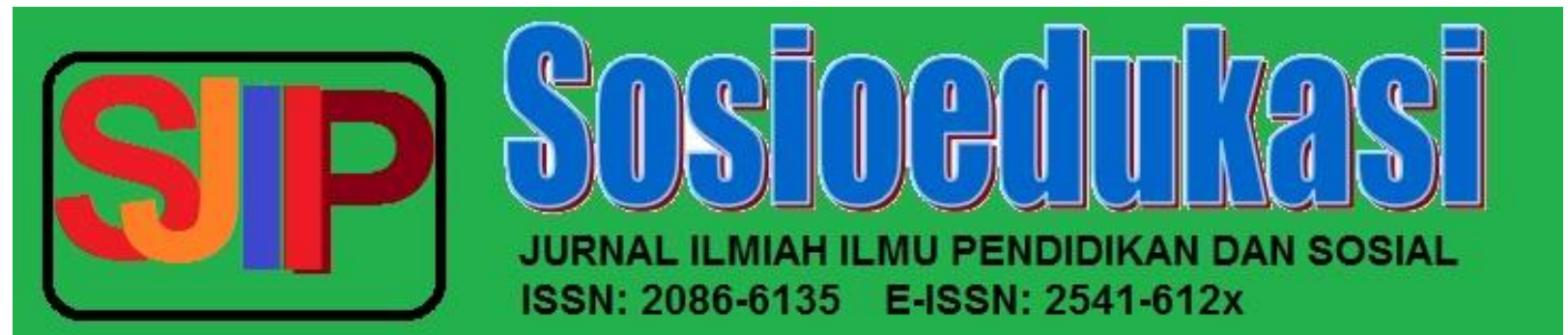

November Vol.9 No. 2 Tahun 2020

https://ejournal.unibabwi.ac.id/index.php/sosioedukasi/index

the things that are assessed are the results or the process itself in the framework of decision making. Shadish (1998) suggested that evaluation theory will lead us to further develop about evaluation and as a knowledge base about our profession.

Stufflebeam, also emphasized the importance of studying evaluation theory and its approach. He wrote, "The study of alternative evaluation approaches is important for professionalizing program evaluation and for its scientific advancement and operation". Many people view that evaluation is a synonym of professional judgment, judgment on the quality of the program based on expert opinion. In the scope of school evaluation is seen as a process of comparing student performance data with the objectives and learning outcomes expected, from there evaluation can be seen as a synonym for controlled experimental research. This view establishes a causal relationship between programs and outcomes.

Several focuses highlighted the importance of naturalistic demand or encouragement of pluralism that needs to be recognized, accommodated and maintained. Another focus has also highlighted the importance of "social equity", arguing that the people involved in the evaluation entity should play an important, even a major role, the role of setting the direction in which evaluation studies are taken and how to do them. (Fitzpatrick, et al. 2012) The lecture program is a teaching plan as a guide for lecturers in carrying out lectures, so that lectures can run well. Lecture programs made by lecturers cannot always be implemented properly.

In connection with this, so that the lecture program that has been created does not have the weaknesses that occur in the next lecture program, it is necessary to evaluate the lecture program, especially for environmental knowledge courses because this is one of the important factors to achieve good educational goals. In this process, the effectiveness of lectures, evaluation factors, both the process and the results of the lecture, also need attention. A program is not just a single activity that can be completed in a short time, but is a continuous activity because it implements a policy.

Therefore, a program can take a relatively long time. The program is an activity unit or activity unit in the

form of a system, namely a series of activities carried out not only once but continuously (Arikunto, 2014). Based on this meaning, the student lecture program can be interpreted as a plan in the form of a series of activities to be carried out in order to achieve a predetermined goal. Planning for student lecture programs by lecturers will help the implementation of these activities to be 


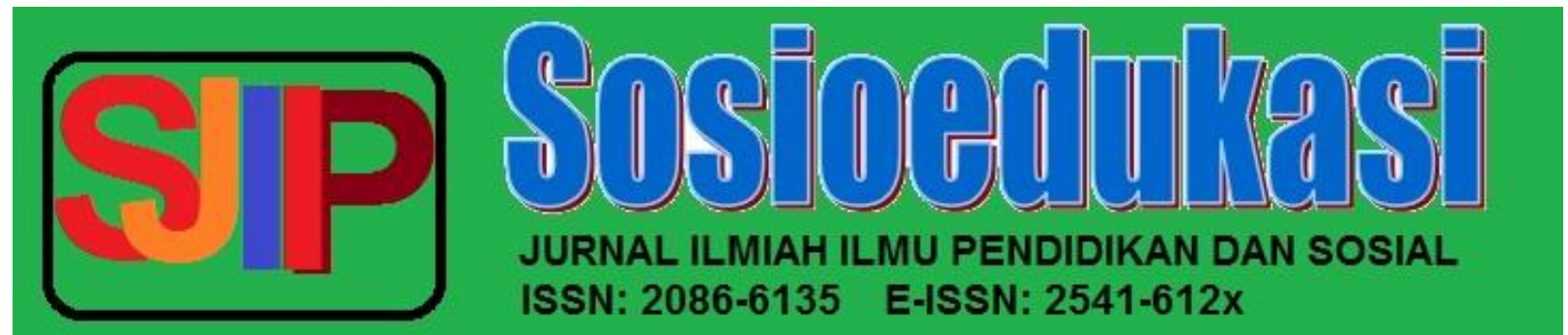

November Vol.9 No. 2 Tahun 2020

https://ejournal.unibabwi.ac.id/index.php/sosioedukasi/index

directed, effective and efficient, so as to improve both the quality and quantity of graduates of a university.

Conversely, if the activity is carried out without being programmed it will reduce the productivity of a college graduation. So far, environmental knowledge lectures have not fully contained Sustainable Development which can improve the Ecology Intelligence of biology teacher candidates. In this connection, the evaluation of the lecture program that will be carried out is for lectures that contain Sustainable Development in order to improve the Ecology Intelligence of prospective biology teachers in environmental knowledge courses.

Program evaluation (Putra, 2017) is a process, which explicitly refers to the achievement of goals, while implicitly evaluation must compare what has been achieved from the program with what should be achieved based on predetermined criteria. In the context of program implementation, the criteria in question are the criteria for the success of the implementation and the things that are assessed are the results or the process itself in the framework of decision making.

Program Evaluation Design is research with certain specificities, program evaluation also requires a proposal and evaluation design. A proposal is a work plan that describes all the activities that will be carried out in the evaluation, complete, detailed, accompanied by costs. The evaluation design is part of the evaluation proposal, so its content is narrower. The evaluation design is a map of the activity journey that will be carried out by the evaluator in conducting the evaluation. The things that must be considered in the evaluation design (Dedy, 2013) are as follows: Evaluation design

\section{a. Activity Title}

State the main content of the evaluation activity which includes the name of the activity, what program is being evaluated (part of the program), and can also include the model used and mention the unit and location of the program.

b. reasons Evaluation Implementation

Explaining theirof the policy program being a target object, estimate the barriers of implementation or the reasons need to be implemented evaluasi.Tujuan

There are two forms of interest, namely general purpose and special purpose, in particular purpose mentioned in detail targets to be achieved from the evaluation. The number of goals is not limited, but represents a limit of at least three sentences, and preferably no more than five sentences. 


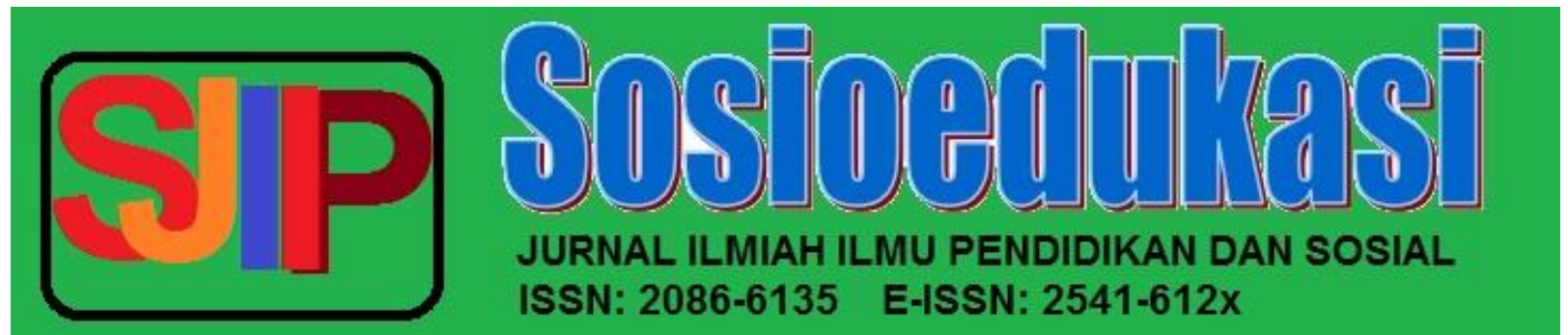

November Vol.9 No. 2 Tahun 2020 https://ejournal.unibabwi.ac.id/index.php/sosioedukasi/index

\section{c. Evaluation Questions}

Formulate several questions to be answered through evaluation activities.

d. The methodology used

Describes the evaluation target object resulting from the identification of program components and indicators, data sources, methods used, instruments used as a complement to data collection methods.

e. Work Procedure and Activity Steps

Discuss matters related to the process that the program evaluation officer will undergo. Based on the title of this material, there are two things that need to be understood, namely work procedures and work steps. Activity steps, namely step by step all activities, from the process of understanding the program, compiling instruments and testing them, collecting data, analyzing data, and compiling reports.

\section{B. General Program Evaluation}

Design The evaluation design of educational programs has the accuracy of the evaluation model, which means that there is a close relationship between program evaluation and the type of program being evaluated. This type of program can be divided into three, namely:

1. Evaluation Design for Processing Programs

The main characteristic of processing programs according to Arikunto (2009) in Sari (2013) is that there are components that can be categorized as raw materials and inputs that are processed in a transformation as processing tools., and strived to be of high quality output. Examples of processing programs are learning programs and scouting programs. In submitting the evaluation design, the evaluation model to be used is determined first, namely the CIPP (Context, Input, Process, and Product) model. A new program evaluation plan can be made if it is known the type of program to be evaluated and the evaluation model. At this time we will make a processing type program evaluation design. In accordance with the outline of the contents of the previous draft, the intended design is:

a. The title of the School Front Cluster activity: Evaluation of the Scouting Program at the Poor Muhammadiyah High School Front Cluster.

b. The reason for conducting the evaluation (outline only): the scouting program has been implemented in this school since (specify by decree if any). So far, the success of this program is not yet known, so a program evaluation is needed. 


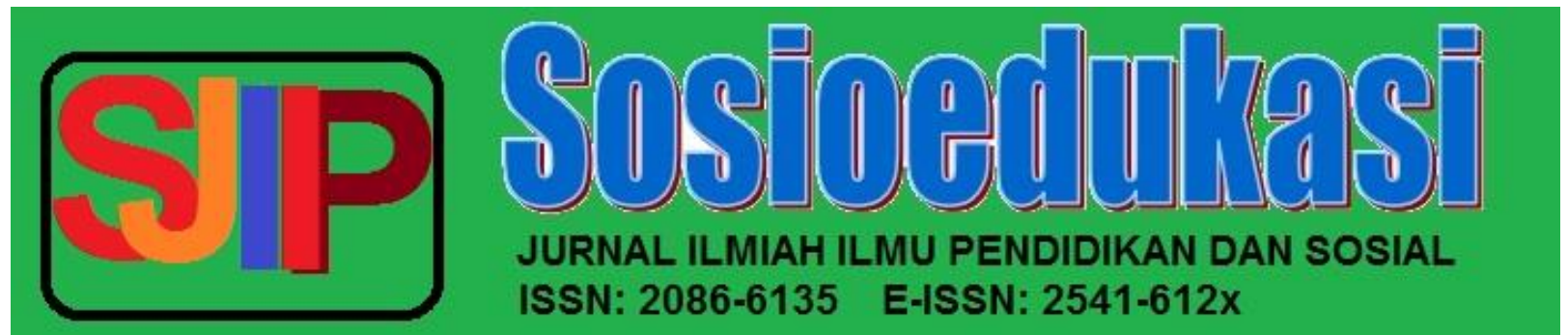

November Vol.9 No. 2 Tahun 2020 https://ejournal.unibabwi.ac.id/index.php/sosioedukasi/index

c. Purpose of activity

1) General objective: the purpose of this activity is to collect information related to the implementation of the scouting program at Kasihan Muhammadiyah Senior High School

2) Specific objective: starting from the general exam, the specific objective of this activity is to determine the level of scouting ability.

d. Evaluation questions

Evaluators must know with certainty the specific objectives formulated to facilitate further thinking and activities, preferably the number (number) of evaluation questions is adjusted to the number of specific objectives.

e. The methodology used

As the target object, evaluation begins when we formulate specific objectives as well as when we formulate evaluation questions. The difference in this section is that the target object must be detailed down to the indicators and sub-indicators, because it will be followed by the preparation of a table of relationships between components-indicators-data-source-method-instrument.

f. Work procedures and activity steps

Before writing work procedures, the evaluator needs to first look at what will be done during the evaluation, as well as write down which parties will be visited, what completeness needs to be prepared. After that the new evaluator ranks the activities according to the appropriate sequence of events or events. Then the evaluator can determine the steps for the activity. Don't forget, complete the design with a plan-op as shown in the example. Another thing that is needed is a time limit or duration of activities.

\section{Evaluation Design for Service Programs An}

example of an evaluation design for a service program is as follows:

1. The title ofactivity the entrepreneurial program evaluationat SMA Muhammadiyah Kasihan.

2. Reasons for the evaluation In this sub-section we write down the types of entrepreneurship that will be evaluated

3. Objectives of the activity

A General The objectiveaim of this activity is to collect information related to the implementation of entrepreneurship programs at Kasihan Muhammadiyah Senior High 


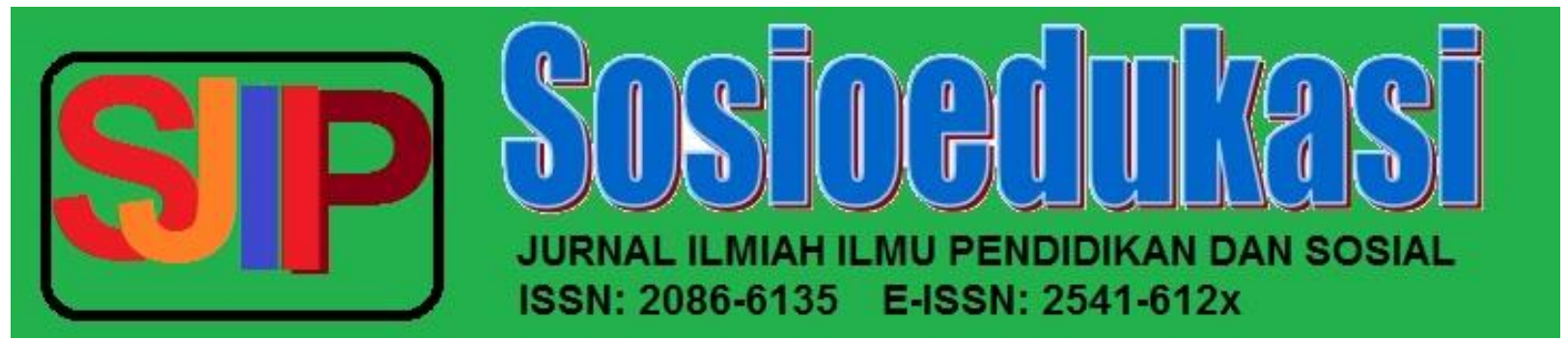

November Vol.9 No. 2 Tahun 2020 https://ejournal.unibabwi.ac.id/index.php/sosioedukasi/index

School. Specific: One of the specific objectivesobjectives is the condition of entrepreneurial equipment (type of equipment, condition or quality, arrangement, and maintenance).

4. Evaluation questions

To formulate evaluation questions, evaluators need to refer to the formulation of specific objectives that have been mentioned.

5. The methodology used.

The object of evaluation in entrepreneurship programs is those that have been mentioned in the specific objectives.

6. Work procedures and activity steps

We already understand the objectives of this evaluation methodology and objectives. So we can make a supposition if the entrepreneurship is in a school near us and we ourselves are the evaluators.

\section{Evaluation Design for General Programs}

Finding examples of general programs is easier than looking for samples of processing type programs or service programs. This is because both programs are processing types and specialized services, whereas general programs are not. For an example of a general program design, we take the picnic program. The arrangement of the design is as follows:

1. Title of activity

evaluation of family picnic program.

2. Reasons for conducting the evaluation.

To write down the background to the problem, we need to know and explain the purpose, reasons, and benefits of the picnic for the family.

3. Activity objectives

a. General

The purposepurpose of the activity is to collect information related to the implementation of the family picnic program.

b. Specific objectives

To be able to formulate specific objectives wefirst mustidentify the components of the picnic program.

4. Evaluation questions 


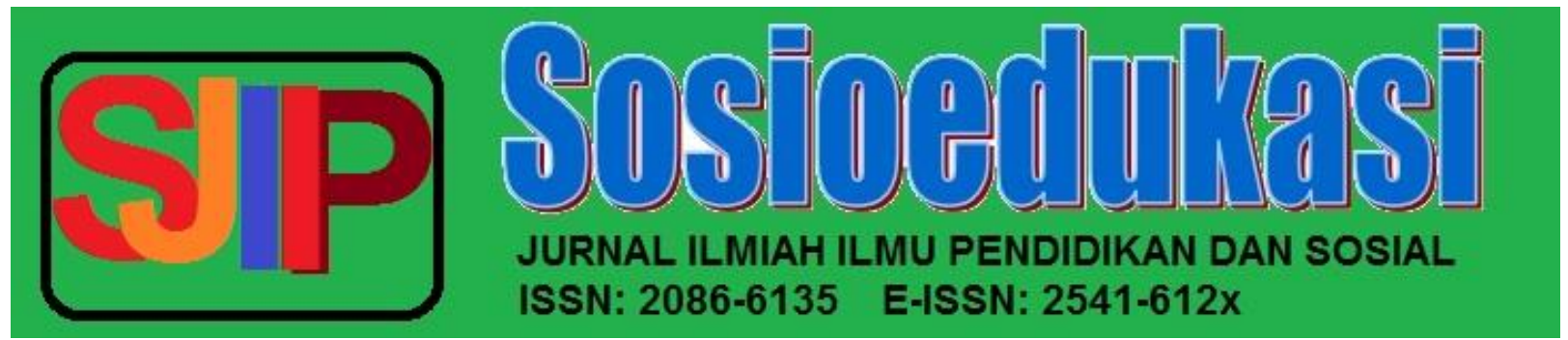

November Vol.9 No. 2 Tahun 2020 https://ejournal.unibabwi.ac.id/index.php/sosioedukasi/index

From the formulation of the specific objectives that have been presented above, then we formulate the evaluation questions. Where the formula must be a question sentence.

5. Methodology used

From the formulation of the specific objectives above, several examples of component details have been given. Then we detail other components that have not been detailed, then we continue to compile a table of relationships between components, indicators, data sources, methods.

6. Work procedures and activity steps

How to write down work procedures and activity steps, because you have already received explanations and examples, you certainly won't have any difficulties.

\section{CONCLUSION}

The program evaluation design is a program evaluation that aims to determine the achievement of program objectives to be implemented. The results of program evaluation are used as a basis for carrying out follow-up activities or for making subsequent decisions. Like research, program evaluation requires a proposal and evaluation design. The difference between a program evaluation proposal and a program evaluation design lies in the emphasis on its content. If the proposal is an activity proposal, the design is a map of the activity journey that will be carried out by the evaluator in carrying out the evaluation.

\section{Suggestions}

Based on the interviews that have been conducted, the evaluators advise the program organizers at Mhammadiyah High Pity that there is a

need for a separate room for the activities of the yoga program so that it does not interfere with teaching and learning activities. Then for the issue of implementation time, the school should also provide separate time so that school residents, especially student activities, are not disturbed. For example, on Friday 07.00-09.00 the culinary program activities. In addition to the need for a special room for the activities of the yoga program and the specified time so that teaching and learning activities are not disturbed, schools also need to provide complete 


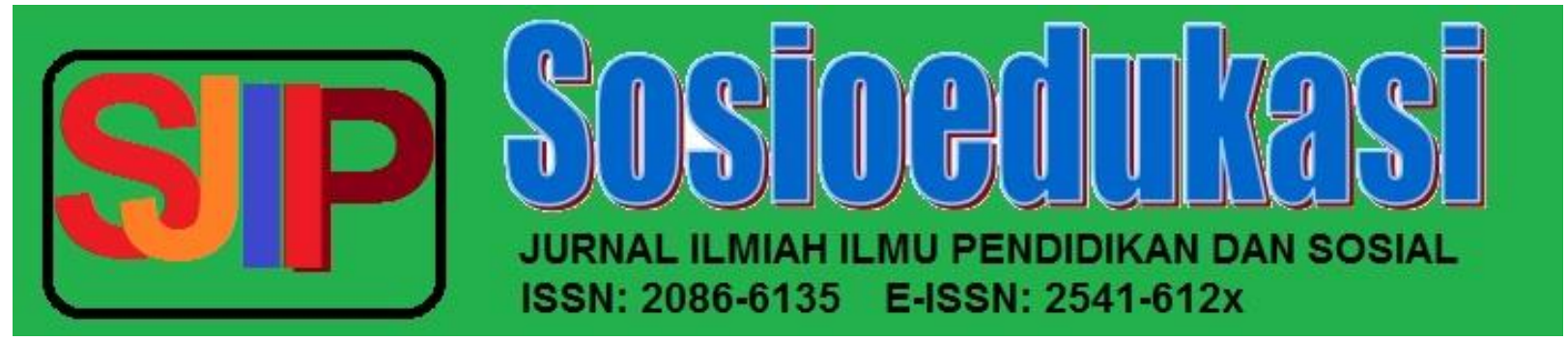

November Vol.9 No. 2 Tahun 2020

https://ejournal.unibabwi.ac.id/index.php/sosioedukasi/index

cooking utensils so that there is no need to borrow from the Aisyiah branch. So that students can use or borrow cooking utensils directly if needed. These cooking utensils can also be used as facilities for students to develop their skills outside of extracurricular hours.

\section{REFERENCES}

Dedy. (2013). Model and Design of Educational Program Evaluation. Papers.

Putra, A. (2017). Evaluation Design of Environmental Knowledge Lecture Program with Sustainable Development (SD) Contents to Improve Ecology Intelligence of Biology Teacher Caolon. Program Evaluation Articles.

Sari, IP (2013). Program Evaluation Design. https://bit.ly/2UmgyGA. Accessed on Friday, 29 March 2019.

Switri, Endang. 2019. Teknologi dan Media Pendidikan Dalam Pembelajaran. Pasuruan: Qiara Media 